\title{
IRRIGATION SYSTEM PERFORMANCE EVALUATION OF SUB IRRIGATION AREA OF JEJERUK KIRI TAMBRAN USING PUBLIC WORKS MINISTER'S REGULATION NO. 32 IN 2007 AND FUZZY SET THEORY
}

\author{
Sahilda Swabawani , Edijatno , Bachmid Tohary \\ Civil Engineering Department, Institute Technology of Sepuluh November \\ Civil Engineering Building $2^{\text {nd }}$ floor, ITS Sukolilo Campus, Surabaya 60111, Indonesia \\ E-Mail: sahildaswabawani@gmail.com
}

\begin{abstract}
Sub irrigation area of Jejeruk Kiri Tambran, physically, has performance degradation due to aging buildings and nature factors. Therefore, performance evaluation of irrigation system is needed as a part of the asset management of irrigation to determine the functioning of the irrigation asset. The procedures of performance evaluation refers to Public Works Minister's Regulation No. 32 in 2007, concerning to Operation and Maintenance of Irrigation System, which is consist of 6 main aspects, there are physical infrastructure, productivity of planting, supporting facilities of operation and maintenance, personnel organization, documentation, and water user farmer association. This kind of evaluation contains fuzziness and uncertainty in valuing based on observation dan human opinion. Hence, a method that can accommodate the problem is needed, one of which is fuzzy set theory method. The aim of this research is comparing performance evaluation of irrigation system by using manual method of Bengawan Solo River Basin Agency which is refers to Public Works Minister's Regulation No. 32 in 2007 and fuzzy set theory. The result performance value of irrigation system of sub Jejeruk Kiri Tambran is $77,69 \%$ based on manual method and $73,45 \%$ based on fuzzy method. By t-test, there is no significant diference between both methods.
\end{abstract}

Keywords : irrigation system, performance evaluation, fuzzy set theory.

\section{INTRODUCTION.}

Strengthening food security has become one of the national priorities contained in the National Medium Term Development Plan (RPJMN) of the Republic of Indonesia Year 2015 to 2019 in which the state is obliged to realize this. One attempt to realize that is by returning rice self-sufficiency by providing infrastructure such as irrigation systems that are reliable.

But over time, the performance of irrigation systems, some of them, have declined and may be caused by the simultaneous effect of the decline in the physical condition of irrigation networks (JI) and the low performance of the operation and maintenance of the irrigation network. The success rate of implementation of the functions of irrigation depends on the performance or the performance of the existing irrigation systems, that it is necessary to be carried out performance evaluation of irrigation.

From many of irrigation systems in Indonesia, particulary in East Java, one of irrigation system that has decreased in performance is sub irrigation area of Jejeruk Kiri Tambran, a part of a part of Jejeruk irrigation area which administratively located in Magetan District, East Java Province and hydrologically as a part of Madiun River sub watershed in Bengawan Solo watershed and under the authority of Bengawan Solo River Basin Agency, Ministry of Public Works and Public Housing (>3.000 ha). Decreased performance, in addition to the age factor of the building, the natural condition factors also cause a lot of facilities and building irrigation networks damaged.

Performance evaluation of irrigation systems in this study refers to the criteria listed in Minister Regulation of Public Works No. 32 of the Operations and Maintenance of Irrigation Network consisting of six aspects, among other aspects of the physical infrastructure, productivity of planting, operation and maintenance supporting facilities, personnel organization, documentation and aspects of water user associations. This evaluation contains an element of subjectivity, fuzziness and uncertainty. Therefore we need a method that can accommodate these elements, then was used the method of fuzzy.

\section{LITERATURE REVIEW}

Based on Public Works Minister's Regulation No. 32 in 2007 concerning to Operation and Maintenance of Irrigation System, evaluation the performance of irrigation system is intended to determine the condition of the performance of the irrigation system.

Performance Evaluation of Irrigation System Manually by Bengawan Solo River Basin Agency

In evaluating performance of irrigation system, Bengawan Solo River Basin Agency use manual evaluation acording to indicators contained in Public Works Minister's Regulation No. 32 in 2007 of the Operations and Maintenance of Irrigation Network. The indicators are shown in the Table 1.

Table-1. Aspects in Evaluation of the Performance of the Irrigation System 


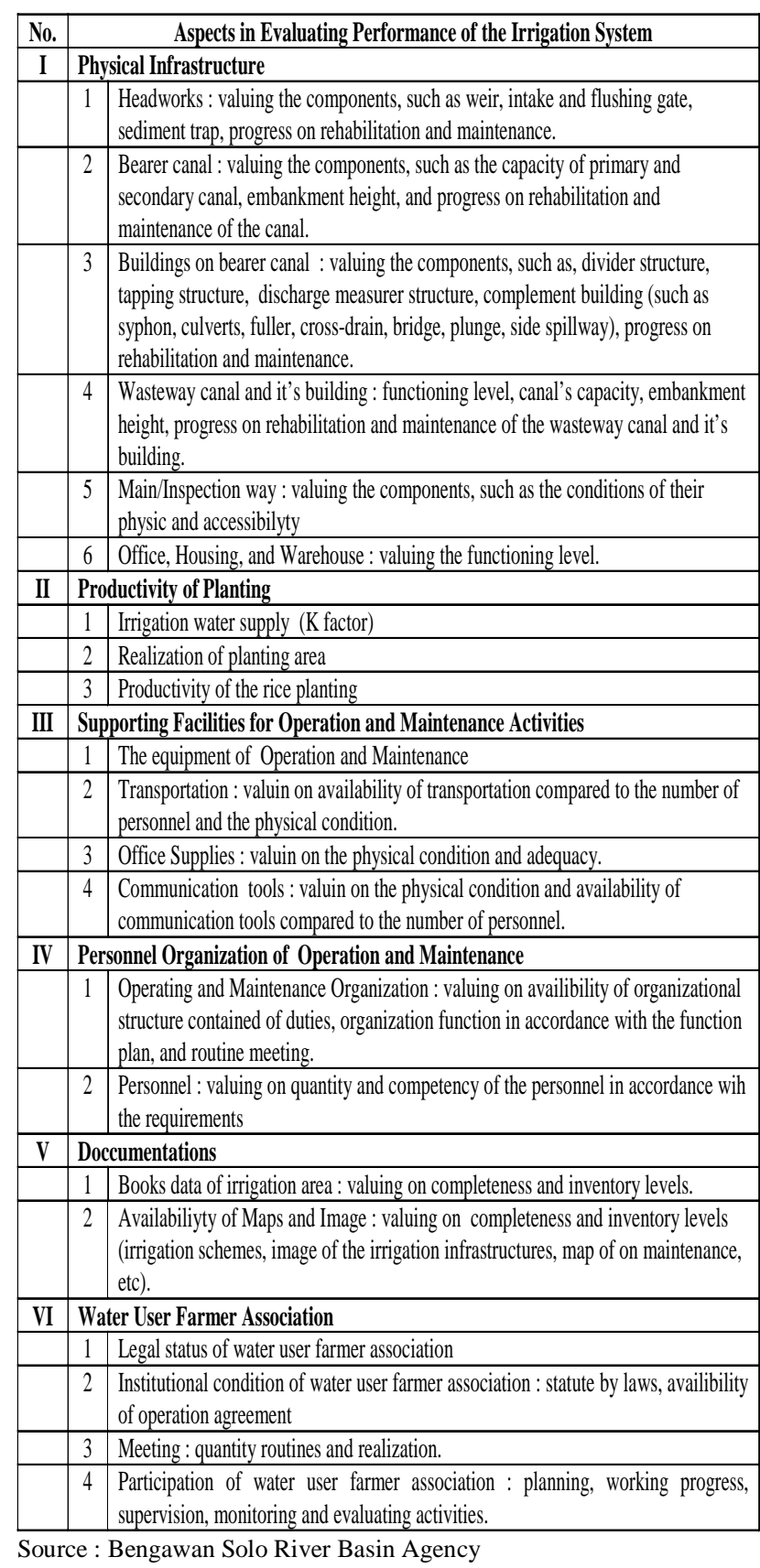

From the Table- 1 above, the third aspect until the last aspect, evaluation of each sub aspect involves the condition in three level of management, there are Bengawan Solo (BS) River Basin Agency, BS representatives's agency, and technical unit of irrigation area named Jejeruk Technical Unit.

Manual evaluation method of Bengawan Solo River Basin Agency is shown in the form of percentage. In valuing the aspects condition, it's devided into three classification value, there are good conditions (80$100 \%)$, good enough (50-79\%), and less conditions (0$49 \%$ ). Evaluation of six aspects are then summed to obtain total value of performance. The resulting value of this evaluation will determine the performance of the irrigation system, with the value of irrigation system performance index as follows :

Table-2. Index of Performance

\begin{tabular}{|l|c|l|}
\hline No. & $\begin{array}{c}\text { Performance Value } \\
(\%)\end{array}$ & \multicolumn{1}{|c|}{ Description } \\
\hline 1. & $80-100$ & Very good performance \\
\hline 2. & $70-79$ & Good performance \\
\hline 3. & $55-69$ & Less/Lack in performance and need attention \\
\hline 4. & $<55$ & Bad performance and need attention \\
\hline
\end{tabular}

The maximum performance is on $100 \%$, the minimum performance is on $55 \%$, and an optimum one is on $77,5 \%$.

\section{Fuzzy Set Theory}

Fuzzy set theory was first introduced by Lotfi Zadeh in 1965. Zadeh introduced the theory that membership in the fuzzy set not in the form of logic true (true) or false (false), but is expressed in degrees (degree). Two types of sets in fuzzy set theory, are, first is crisp set, membership value is one (1), which means that an item becomes a member in a set or, zero (0) which means that an item is not a member in a set. Second is fuzzy set, membership is stated as membership values that the value is located in the interval of $0-1$ (Kusumadewi, 2004). If $\mu(x)=\mu$ withn $0<\mu<1$, then $x$ is a member of the set with a degree of membership.

The membership function defines how each point in the input space is mapped into weights or degrees of membership which has the interval between 0 and 1. The method for obtaining membership function such as by using statistical methods, and method by using data obtained through interviews with humanexpert (experts).

The logic of fuzzy works based on the rules stated in the form of IF-THEN statement. With fuzzy rules all knowledge and human experience can be presented through a natural language called IF-THEN rules. Common forms of rule for fuzzy :

IF $x$ is A THEN $y$ is B. be expanded using fuzzy operator :

IF $\left(x_{1}\right.$ is $\left.A_{1}\right)$ o $\left(x_{2}\right.$ is $\left.A_{2}\right)$ o $\left(x_{3}\right.$ is $\left.A_{3}\right)$ o ... o $\left(x_{n}\right.$ is $\left.A_{n}\right)$ THEN $\mathrm{y}$ is $\mathrm{B}$........(2.2),

where $\mathrm{o}$ is the fuzzy operator. Operator fuzzy functions to combine and modify sets of fuzzy, consisting of operators such as AND, OR, and NOT.

FIS is a helping tool to model based on the sets of fuzzy theory utilizing rules of fuzzy IF-THEN thus may be able to model input variable in nature of fuzzy, becoming output variable in nature of crisp or thinking aspect or human opinion in nature of qualitative becomes quantitative. The structure of FIS consists of variabels such as input, fuzzification, rules of fuzzy, variable of output, and defuzzification. The structure of FIS can be seen in FIgure 1.

Figure-1. Fuzzy Inference System Structure

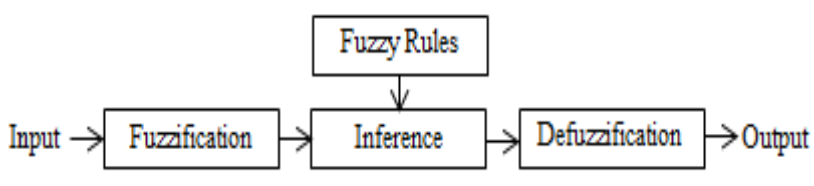

Fuzzification is a process of changing the input from the form of (crisp) becomes fuzzy (linguistic variable) that are usually presented in the form of fuzzy associations with its membership function respectively. 
The output of this fuzzyfication process is a fuzzy input . Defuzzification (crisp) is the opposite of the process of fuzzification, where its input in the form of fuzzy input and its output is a single number to be inserted into a variable output of Fuzzy Inference System (FIS).

The advantage of fuzzy inference system is able to translate the knowledge of experts in the form of rules, but usually takes a long time to set membership functions. Therefore, it takes learning techniques of artificial neural networks to automate the process so as to reduce search time. Techniques that can be used is ANFIS, merging mechanism of fuzzy inference system described in the architecture of neural networks or in other words the neural network used to implement fuzzy inference system.

\section{METHODS}

The performance evaluation of irrigation systems Sub IN Jejeruk Kiri Tambran in this study using the manual method of BBWS Bengawan Solo. The process study of this resarch shown in the Figure 2.

Figure-2. Process Study

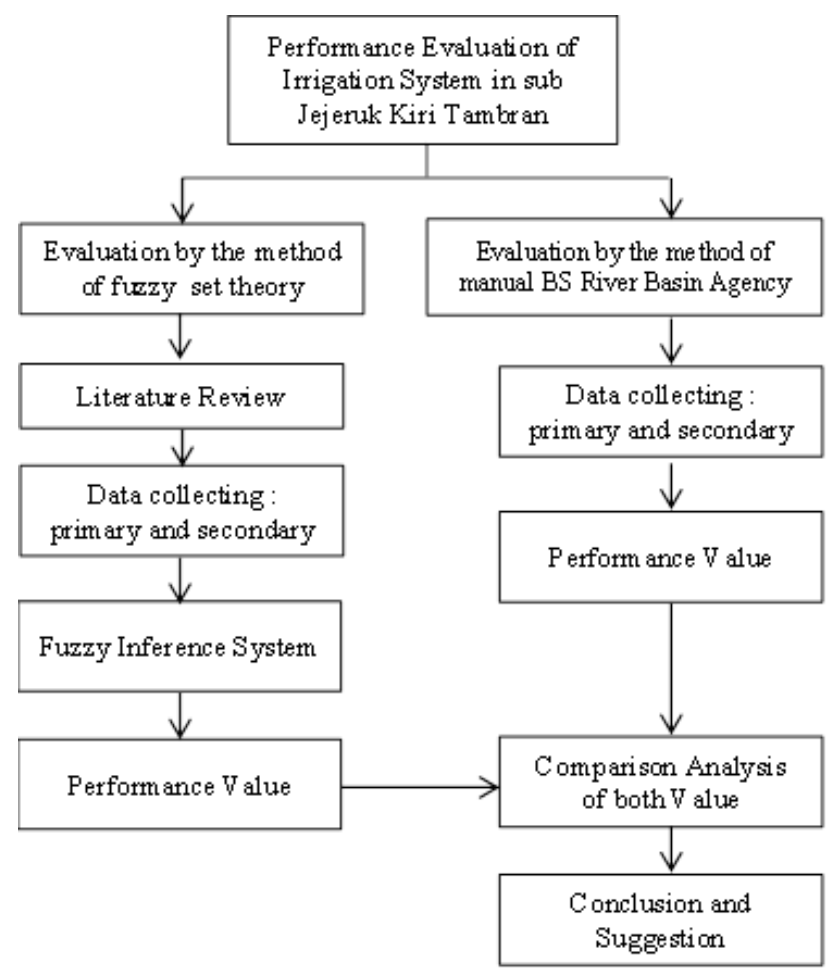

\section{Irrigation System Performance Evaluation by the method of Manual Bengawan Solo River Basin Agency}

Evaluation with the manual method is done by observing the condition of the irrigation system in the field of the aspects of irrigation system performance evaluation in accordance with Public Works Minister's Regulation No.32 Year 2007 on guidelines for Operation and Maintenance of Irrigation. The evaluation criteria described in Table 2.1. The observation of conditions in the field of irrigation systems for physical facilities and infrastructure is done by tracking irrigation network starting from upstream to downstream.
Observation activities were resulting in Physical Condition Value (PCV) representing the existing condition at that time corresponding to the manual evaluation criteria. Results of PCV then multiplied with weight value of each parameter to obtain Weight Condition Value (WCV). Subsequently, PCV from each aspects were then added up to obtain the total value of Weight Condition Value (WCV). Then, PVC from each aspects were addep up to obtain the total value of PVC. Total value of PVC was then become the whole irrigation system performance value.

This research needs both primary and secondary data. The needs of the data is shown in the Table-3.

Table-3.

\begin{tabular}{|c|c|}
\hline Type of the data & Method of data colecting \\
\hline $\begin{array}{l}\text { Secondary data : } \\
\text { 1. Data of location } \\
\text { 2. Map and schemes of sub Jejeruk Kiri } \\
\text { Tambran irrigation area } \\
\text { 3. Inventory data of physical infrastructures of } \\
\text { irrigation } \\
\text { 4. Data of rice planting productivity } \\
\text { 5. Data of operation and maintenance } \\
\text { supporting facilities } \\
\text { 6. Data of operation and maintenance } \\
\text { 7. Datan of the documetation } \\
\text { 8. Data of water user farmers association }\end{array}$ & $\begin{array}{ll}\text { 1. } & \text { BS river basin agency } \\
\text { 2. Technical Unit of Jejeruk } \\
\text { Kiri Tambran } \\
\text { 3. Public Works Agency of } \\
\text { Water Resources of } \\
\text { Magetan District }\end{array}$ \\
\hline $\begin{array}{l}\text { Primary data : } \\
\text { 1. The physical condition of sub Jejeruk Kiri } \\
\text { Tambran irrigation network }\end{array}$ & 1. Observation \\
\hline
\end{tabular}

\section{Evaluation of Irrigation System Performance with} Fuzzy Set Theory Method

FIS analysis was done on each aspects of irrigation system performance in tota of 6 (six) aspects and 21 (twenty one) sub aspects. Output from each FIS then were added up to obtain performance value of irrigation system in whole.

The formation of membership function done by using direct rating method, namely by involving experts (irrigation management) in making decision to determine the degree of membership through interview. Sample collection technique to determine the respondents who will be interviewed was by purposive sampling technique. In this research, requirement made as the sample was an expert where someone is expected to have competency in the field of irrigation and experienced in implementing irrigation network physical condition, namely irrigation manager.

Formation of fuzzy rules using ANFIS to automate the establishment of the rule by learning techniques to a set of inputs and outputs (Kusumadewi, 2006). ANFIS can help save time in the process. In determining the number of fuzzy rules, based on the formula of $x^{n}$ where $x$ is the number of sets (low, sufficient, and good sets), whereas $n$ is the number of indicators (input variables). The process of ANFIS used Sugeno orde 0 method by simple considerations and make easy the computation process if fuzzy rule in large amount.

Defuzzification is the process that converts the output results of the combination of fuzzy rules become an assertive value. The method used in the process of defuzzification is weighted average method. 
The 2nd International Conference on Civil Engineering Research (ICCER) 2016

"Contribution of Civil Engineering toward Building Sustainable City"

After obtaining the results of evaluation from each method either by manual BBWS Bengawan Solo or fuzzy set theory, subsequent phase is to perform hypothesis test by using t-test. One of the forms of t-test is paired sample t-test. Paired sample t-test, can be used in the same sample, however the testing used two different methods.

\section{RESULT AND DISCUSSIONS}

Irrigation System Performance Evaluation by a Method of Manual BBWS Bengawan Solo

Results of the evaluation aspects and subaspects of the performance of the irrigation system according to Public Works Minister's Regulation No.32 Year 2007 on guidelines for Operation and Maintenance of Irrigation as shown in the Table 4 below.

Table-4. Result of the evaluation performance of Sub Jejeruk Kiri Tambran Irrigation Area

\begin{tabular}{|c|c|c|c|c|c|}
\hline No. & & $\begin{array}{l}\text { Aspects of Irrigation System } \\
\text { Performance Evaluation }\end{array}$ & $\begin{array}{c}\text { Standard } \\
\text { Weight } \\
\text { Value } \\
(\%)\end{array}$ & $\begin{array}{l}\text { Physical } \\
\text { Condition } \\
\text { Value } \\
\text { (PCV) } \\
\text { (\%) }\end{array}$ & $\begin{array}{c}\text { Weight } \\
\text { Condition } \\
\text { Value } \\
\text { (WCV) } \\
\text { (\%) }\end{array}$ \\
\hline & & $\begin{array}{l}\text { Total Performance Value of } \\
\text { Irrigation System }\end{array}$ & 100 & & 77,69 \\
\hline \multirow[t]{7}{*}{$\mathbf{I}$} & \multicolumn{2}{|r|}{$\begin{array}{l}\text { Physical Infrastructures of } \\
\text { Irrigation Network }\end{array}$} & 45 & 59,3 & 35,00 \\
\hline & 1 & Headworks & 13 & 77,62 & 10,69 \\
\hline & 2 & Bearer canal & 10 & 69,44 & 6,94 \\
\hline & 3 & Buildings on bearer canal & 9 & 70,99 & 7,89 \\
\hline & 4 & $\begin{array}{l}\text { Wasteway canal and it's } \\
\text { structures }\end{array}$ & 4 & 80,00 & 3,2 \\
\hline & 5 & Inspection way & 4 & 78,75 & 3,15 \\
\hline & 6 & Office, houses, and warehouse & 5 & 74,50 & 3,73 \\
\hline II & \multicolumn{2}{|r|}{ Productivity of Planting } & 15 & 90,16 & 13,53 \\
\hline & 1 & $\begin{array}{l}\text { Irrigation water supply (K } \\
\text { factor) }\end{array}$ & 9 & 89,00 & 8,01 \\
\hline & 2 & Realization of planting area & 4 & 91,40 & 3,66 \\
\hline & 3 & Rice planting produktivity & 2 & 92,90 & 1,86 \\
\hline \multirow[t]{5}{*}{ III } & \multicolumn{2}{|r|}{$\begin{array}{l}\text { Operation and Maintenance } \\
\text { Supporting Facilities }\end{array}$} & 10 & 59,50 & 5,95 \\
\hline & 1 & $\begin{array}{l}\text { Operation and Maintenance } \\
\text { Equipment }\end{array}$ & 4 & 46,88 & 1,88 \\
\hline & 2 & Means of Transportation & 2 & 58,75 & 1,18 \\
\hline & 3 & $\begin{array}{l}\text { Operation and Maintenance } \\
\text { Office Tools }\end{array}$ & 2 & 75 & 1,5 \\
\hline & 4 & Means of Communication & 2 & 70 & 1,4 \\
\hline \multirow[t]{3}{*}{ IV } & \multicolumn{2}{|r|}{ Personnel Organization } & 15 & 78,67 & 11,80 \\
\hline & 1 & $\begin{array}{l}\text { Operation and Maintenance } \\
\text { Organization }\end{array}$ & 5 & 8,40 & 4,20 \\
\hline & 2 & Personnel & 10 & 76 & 7,60 \\
\hline \multirow[t]{3}{*}{$\mathbf{V}$} & \multicolumn{2}{|r|}{ Documentation } & 5 & 70,20 & 3,51 \\
\hline & 1 & Books Data of Irrigation Area & 2 & 78 & 1,56 \\
\hline & 2 & Maps and Images & 3 & 65 & 1,95 \\
\hline \multirow[t]{5}{*}{ VI } & \multicolumn{2}{|r|}{ Water User Farmers Association } & 10 & 79 & 7,90 \\
\hline & 1 & Legal status & 1,5 & 100 & 1,50 \\
\hline & 2 & Institutional Conditions & 0,5 & 70 & 0,35 \\
\hline & 3 & Meeting & 2 & 70 & 1,40 \\
\hline & 4 & Participation & 6 & 77,50 & 4,65 \\
\hline
\end{tabular}

The value of Jejeruk Kiri Tambran irrigation system performance using manual method of BS River Basin Agency is 77,69\%. The value is included in good performance criteria.

\section{Irrigation System Performance Evaluation with a Method of Fuzzy Set Theory}

The performance evaluation of irrigation systems using fuzzy set theory analyzed in Matlab software. The results of performance evaluation of irrigation system which consists of six main aspects will be used as input data in the evaluation by the method of fuzzy.
The value of irrigation system performance using fuzzy set theory as shown in the Table 5 below.

Table-5. The Value of Irrigation System Performance by Fuzzy Set Theory Method

\begin{tabular}{|c|l|c|}
\hline No. & \multicolumn{1}{|c|}{ Description } & $\begin{array}{c}\text { Output Value Of Evaluation by } \\
\text { Fuzzy Set Theory Method (\%) }\end{array}$ \\
\hline 1. & Physical Infrastructures & 36,85 \\
\hline 2. & Plant Productivity & 13,29 \\
\hline 3. & $\begin{array}{l}\text { Supporting Facilities for } \\
\text { Operation and Maintenance }\end{array}$ & 5,24 \\
\hline 4. & Personnel Organization & 8,80 \\
\hline 5. & Documentation & 2,76 \\
\hline 6. & $\begin{array}{l}\text { Assembly of Water Users } \\
\text { Association }\end{array}$ & 6,52 \\
\hline & Total Performance Value & $\mathbf{7 3 , 4 5}$ \\
\hline
\end{tabular}

The value of Jejeruk Kiri Tambran irrigation system performance using fuzzy set theory method is $73,45 \%$. The value is included in good performance criteria.

The difference between the value of the irrigation system performance evaluation using manual method of BS River Basin Agency and fuzzy set theory method as shown in the Table- 6 below.

Table-6. The Performance Value of Sub Jejeruk Kiri Tambran Irrigation System

\begin{tabular}{|c|c|c|c|}
\hline \multirow{2}{*}{ No. } & \multirow{2}{*}{$\begin{array}{l}\text { Aspects of Irrigation System } \\
\text { Performance Evaluation }\end{array}$} & \multicolumn{2}{|c|}{$\begin{array}{c}\text { The Value of Irrigation System } \\
\text { Performance (\%) }\end{array}$} \\
\hline & & $\begin{array}{l}\text { Method of Manual BS } \\
\text { River Basin Agency }\end{array}$ & $\begin{array}{c}\text { Fuzzy Set Theory } \\
\text { Method }\end{array}$ \\
\hline 1 & $\begin{array}{l}\text { Physical Infrastructures of } \\
\text { Irrigation Network }\end{array}$ & 35 & 36,85 \\
\hline 2 & Productivity of Planting & 13,53 & 13,29 \\
\hline 3 & $\begin{array}{l}\text { Supporting Facilities of Operation } \\
\text { and Maintenance }\end{array}$ & 5,95 & 5,24 \\
\hline 4 & Personnel Organization & 11,8 & 8,8 \\
\hline 5 & Documentation & 3,51 & 2,76 \\
\hline 6 & Water User Farmers Association & 7,9 & 6,52 \\
\hline & Total & 77,69 & 73,45 \\
\hline
\end{tabular}

There is a difference in value between the performance of the manual method and fuzzy method for $4,24 \%$. Then the value of the difference is tested by t-test to determine whether there is a significant difference. Hypothesis that can be arranged are :

$\mathrm{H}_{0}=\mu_{1}=\mu_{2}$

$\mathrm{H}_{1}=\mu_{1} \neq \mu_{2}$

Sig.level $=5 \%$

T-test is done by comparing $t_{\text {counted }}$ and $t_{\text {table }}$.

$\mathrm{t}_{\text {counted }}<\mathrm{t}_{\text {table }}=\mathrm{H}_{0}$ is accepted

$1,094<2,447=\mathrm{H}_{0}$ is accepted, which means there is no significant difference between the performance evaluation of irrigation systems using both manual method of BS River Basin Agency and fuzzy method. 


\section{CONCLUSION}

1. According to Public Work Minister's Regulation No.32 of 2007 on Operation and Maintenance Guidlines of Irrigation Network the value of irrigation system performance either using manual method of BS River Basin Agency and fuzzy set theory, included in the criteria for good performance (70-79\%).

2. Evaluation of the performance of the irrigation system by using the 2 (two) methods resulted in a difference of $4.24 \%$, that in hypothesis test there is no significant difference. This shows that the evaluation of the performance of the irrigation system either using manual method of BBWS BS and method of fuzzy set theory can be used to evaluate the performance of irrigation systems.

\section{REFERENCES}

[1] Ministry of Public Works. 2007. Guidlines of Operation and Maintenance of Irrigation Network. Ministry of Public Works, Jakarta.

[2] Kusumadewi, S.,Hartati,S. 2006. Neuro Fuzzy: Fuzzy Systems Integration And Neural Networks. Graha Ilmu, Jakarta.

[3] Kusumadewi, S., Purnomo,H. 2004. Application Of Fuzzy Logic For Decision Support. Graha Ilmu, Yogyakarta. 